\title{
PEMBERDAYAAN MASYARAKAT PADA PROGRAM PNPM MP, DESA PERADABAN, CSR DAN POSDAYA (KONTEKS LAHIRNYA UU NO. 6 TAHUN 2014)
}

\author{
COMMUNITY EMPOWERMENT ON PRORAM \\ PNPM MP, DESA PERADABAN, CSR AND POSDAYA \\ (CONTEXT OF THE UU NO. 6 TAHUN 2014)
}

\author{
Rahmawati Ahfan, Asrori, dan Hotnier Sipahutar \\ Badan Penelitian dan Pengembangan (BPP) Kementrian Dalam Negeri \\ Jl. Kramat Raya No. 132 - Senen, Jakarta \\ No. Telp./Faks : +62 213140454 ; HP: 085281700111 \\ Email : rioavansa70@yahoo.com
}

Dikirim: 21 Desember 2014 Direvisi: 20 Januari 2015 Disetujui: 26 Februari 2015

\begin{abstract}
Abstrak
Sebelum Undang-Undang Nomor 6 Tahun 2014 tentang Desa dikeluarkan, belum ada peraturan perundangan yang secara eksplisit mengatur tugas, fungsi, wewenang, anggaran pemerintah desa dalam konteks pemberdayaan masyarakat. Tujuan kajian adalah untuk mengidentifikasi program pemberdayaan masyarakat desa sebelum berlakunya UU No. 6 Tahun 2014 dan mengkaji aspek pemberdayaan masyarakat desa dalam UU No. 6 Tahun 2014. Kajian ini menggunakan pendekatan kualitatif dan bersifat eksplanatory, dengan teknik analisis kualitatif. Program pemberdayaan masyarakat dalam kajian ini fokus pada 4 program (PNPM MP, Desa Peradaban, CSR dan Posdaya) tidak sepenuhnya relevan dengan Undang Undang No. 6 Tahun 2014 dimana keterlibatan kelembagaan pemerintah desa dalam pemberdayaan secara struktural masih lemah. Pemerintah desa belum melakukan fungsi pemberdayaan masyarakat disebabkan belum adanya pelimpahan kewenangan dan pembiayaan dari pemerintah kabupaten. Sementara pemberdayaan masyarakat desa yang sesuai dengan Undang-Undang No. 6 Tahun 2014 menekankan pada aspek: keterlibatan aktor penyelenggara pemberdayaan masyarakat; Arah pemberdayaan masyarakat; Aspek kolaboratif pembangunan desa dalam pemberdayaan masyarakat; Pelaksana pemberdayaan masyarakat; Pelembagaan percepatan pemberdayaan masyarakat; dan Etika/ norma pemberdayaan masyarakat.

Kata Kunci: Pemberdayaan Masyarakat, Undang-Undang Nomor 6 Tahun 2014, Partisipasi
\end{abstract}

\begin{abstract}
Before Undang-Undang Number 6 Year 2014 about Village was issued, there is no legislation that explicitly set the task, the function, the authority, budget the village government in the context of community empowerment. Objectives of the study is to identify rural community empowerment program before the enactment of Undang-Undang Nomor 6 Tahun 2014 and assess the empowerment community aspect in Undang-Undang Nomor 6 Tahun 2014. This study used a qualitative approach and are explanatory, with qualitative analysis techniques. Community empowerment programs in this study focus on 4 program (PNPM MP, Desa Peradaban, CSR and Posdaya) not entirely relevant to Undang Undang Nomor 6 Tahun 2014 because government institutions in empowering involvement village structurally weak. The village administration has not carried out the empowerment function caused the absence of the community delegation of authority and financing from the district government. While community empowerment models villages that in accordance with Undang Undang Nomor 6 Tahun 2014 focused on aspects: the involvement of the community empowerment actor; The direction of community empowerment; A collaborative aspects village development in community empowerment; Community empowerment implementing; Institutionalization of community empowerment acceleration; and ethics/ a norm community empowerment.
\end{abstract}

Keywords: Community Empowerment, Undang-Undang Nomor 6 Tahun 2014, Partisipation

\section{PENDAHULUAN}

Secara umum pelaksanaan pemberdayaan masyarakat di wilayah perdesaan selama ini kurang optimal disebabkan belum adanya penyerahan kewenangan dari pemerintah kabupaten/ kota kepada pemerintah desa, belum adanya dukungan anggaran serta pendekatan pembangunan masih bersifat top down. Sedangkan pemerintah desa dalam melaksanakan pemberdayaan masyarakat memerlukan dukungan politik (political will) dari pemerintah provinsi, kabupaten/kota sehingga pemerintah desa memiliki kewenangan dan dukungan anggaran yang jelas serta mengedepankan 
pendekatan bottom up system.

Sebelum lahirnya regulasi Undang-Undang (UU) Nomor 6 Tahun 2014 tentang Desa, belum ada peraturan perundangan yang secara eksplisit mengatur tugas, fungsi, wewenang, anggaran pemerintah desa dalam konteks pemberdayaan masyarakat. Eksistesi UU No. 6 Tahun 2014 secara tegas menjelaskan mengenai pemberdayaan masyarakat sebagaimana tertuang dalam pasal 1 ayat 12. Pasal tersebut berbunyi: "pemberdayaan masyarakat desa adalah upaya mengembangkan kemandirian dan kesejahteraan masyarakat dengan meningkatkan pengetahuan, sikap, keterampilan, perilaku, kemampuan, kesadaran, serta memanfaatkan sumber daya melalui penetapan kebijakan, program, kegiatan, dan pendampingan yang sesuai dengan esensi masalah dan prioritas kebutuhan masyarakat desa”. Lebih lanjut dalam pasal 18 disebutkan: "Kewenangan desa meliputi kewenangan di bidang penyelenggaraan pemerintahan desa, pelaksanaan pembangunan desa, pembinaan kemasyarakatan desa dan pemberdayaan masyarakat desa berdasarkan prakarsa masyarakat, hak asal usul dan adat istiadat desa”.

Melalui hadirnya UU No 6 Tahun 2014 tersebut apakah pemberdayaan masyarakat desa yang dilakukan selama ini masih relevan dengan UU No. 6 Tahun 2014? Permasalahan tersebut dijabarkan dalam beberapa pertanyaan berikut: (1) bagaimanakah konsepsi dan kelembagaan pendukung pemberdayaan masyarakat pada program PNPM MP, Desa Peradaban, CSR dan Posdaya?; (2). bagaimanakah partisipasi masyarakat pada tahap perencanaan, pelaksanaan, pemantauan dan evaluasi?; (3). bagaimanakah dinamika program PNPM MP, Desa Peradaban, CSR dan Posdaya dan aspek-aspek pemberdayaan masyarakat dalam UU No. 6 Tahun 2014 sebagai kebijakan antisipatif?

1. Tujuan Umum

Mengidentifikasi program pemberdayaan masyarakat desa sebelum berlakunya UU No. 6 Tahun 2014 dan mengkaji aspek pemberdayaan masyarakat desa dalam UU No. 6 Tahun 2014.

2. Tujuan Khusus

a. Menganalisis konsepsi dan kelembagaan pendukung pemberdayaan masyarakat pada program PNPM MP, Desa Peradaban, CSR dan Posdaya.

b. Menganalisis partisipasi masyarakat pada tahap perencanaan, pelaksanaan, pemantauan dan evaluasi.

c. Merumuskan dinamika program PNPM MP, Desa Peradaban, CSR dan Posdaya dan aspek-aspek pemberdayaan masyarakat dalam UU No. 6 Tahun 2014 sebagai kebijakan antisipatif.

\section{METODE}

Upaya penyusunan model dari tindakan sosial secara kualitatif beberapa kali dilakukan oleh Max Weber (1964), seperti tipe ideal birokrasi dan otoritas. Metode kualitatif yang dikembangkannya dikenal sebagai verstehen (pemahaman), karena diarahkan untuk memahami makna atau arti dari tindakan sosial. Menurut Weber (1978) tindakan individu diarahkan oleh persepsinya tentang perkiraan respons pihak lain untuk menjawab tindakannya. Penilaian subyektif menjadi penting, karena mendasari tindakan-tindakan sosial yang memiliki makna. Arti subyektif ditunjukkan oleh pengaruh dari konteks sosial berupa ruang dan waktu tertentu, yang melandasi pilihan untuk melakukan tindakan. Dalam kajian ini yang digali ialah tindakan-tindakan individu yang dimaknai sebagai pemberdayaan masyarakat. Rumusan tindakan pemberdayaan masyarakat ialah ketika individu melakukan tindakan secara subyektif mengharapkan respons berupa keputusan dari pihak lain untuk berpartisipasi dalam pembangunan.

Lompatan dari penelitian lapangan menuju konsep yang abstrak disebut Weber (1949) sebagai tipe ideal (ideal type). Makna ideal di sini bukan dalam arti moral, makna ideal berada dalam konstruksi ilmu pengetahuan yang obyektif yaitu sebagai ide-ide yang akan digunakan untuk menjelaskan keadaan lapangan. Melalui cara pandang tipe ideal secara evaluatif ini, maka abstraksi dapat disusun dari hasil kajian lapangan mengenai pemberdayaan masyarakat. Meliputi predisposisi atau alasan tindakan sosial, dan respons terhadap tipe-tipe tindakan sosial yang berbeda-beda. Dalam mengkaji program pemberdayaan masyarakat desa yang relevan dengan UU No. 6 Tahun 2014 perlu melihat pola pemberdayaan masyarakat desa yang telah dilakukan selama ini seperti pada program PNPM MPd, Desa Peradaban, Program CSR dan Pos Daya. Kerangka konseptual studi ini tercermin dalam Gambar 1.

Studi ini menggunakan pendekatan kualitatif dimana data dan analisis yang digunakan pun bersifat kualitatif. Dalam kajiian ini menggunakan metode penelitian deskriptif dan bersifat eksplanatory.

Jenis data dalam kajian ini yaitu kualitatif dari sumber primer dan sumber sekunder. Sumber primer pada kajian ini didapat dari catatan hasil wawancara, lock book hasil observasi mencakup situasi dan kejadian di lapangan. Data sekunder diperoleh dari hasil kepustakaan dengan membaca literatur yang relevan dengan tulisan ini. Teknik analisis mengolah data kualitatif dilakukan melalui tahap reduksi, penyajian data, dan penarikan kesimpulan.

Studi ini dilaksanakan di Bandung Barat,

Kota Bogor, dan Kabupaten Bogor. Penentuan lokus kajian diambil dengan alasan di Kabupaten Bandung Barat terdapat program Desa Peradaban, program CSR Pertamina dan PNPM 


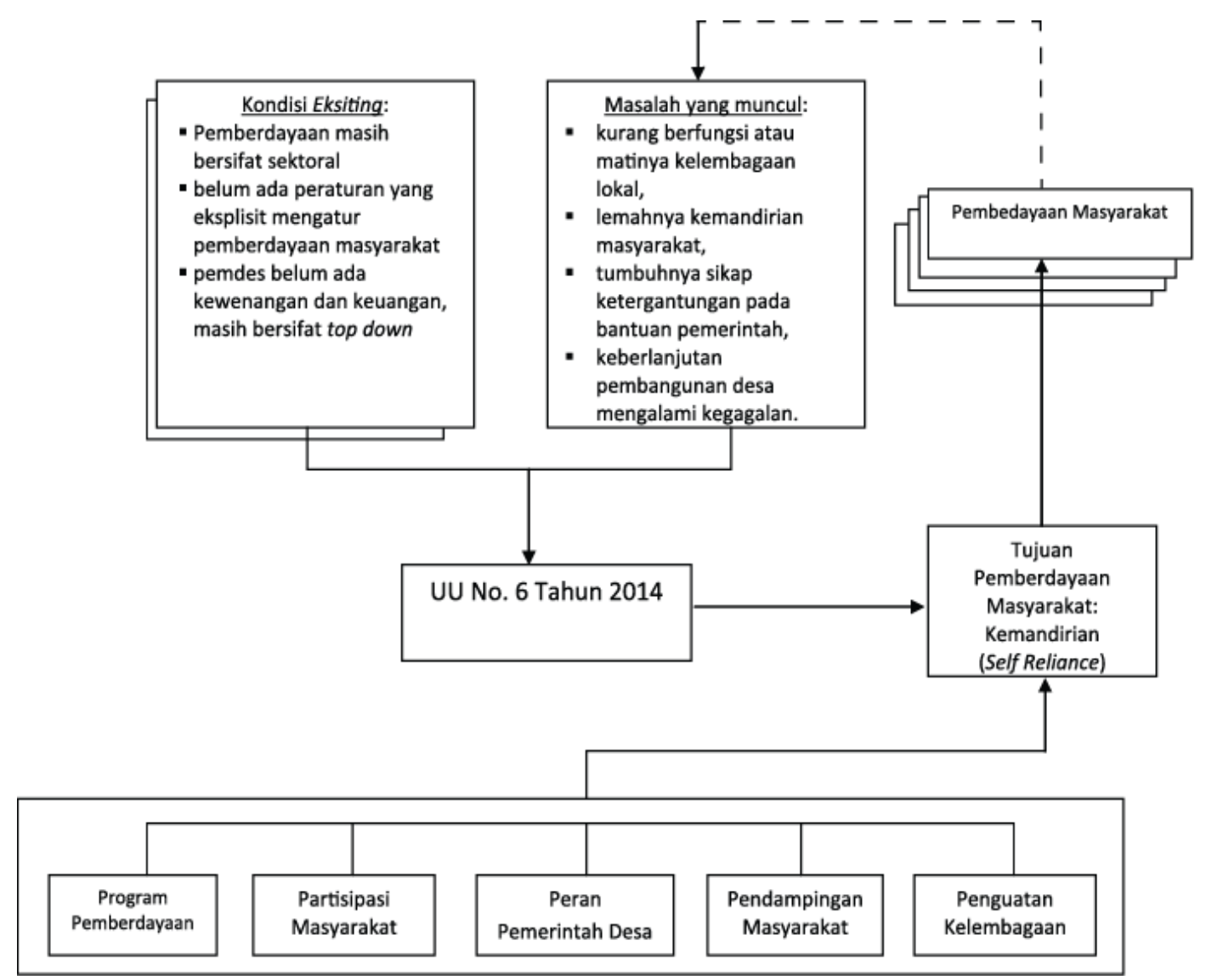

Gambar 1. Diagram Kerangka Pemikiran Pemberdayaan Masyarakat Desa

MP. Di kota Bogor terdapat program Pos Daya yang dikembangkan oleh IPB dan di Kabupaten Bogor terdapat Desa Adat. Sementara waktu kajian dilakukan pada bulan September sampai November 2014.

\section{HASIL DAN PEMBAHASAN}

\section{Konsepsi dan Kelembagaan Pendukung Program Pemberdayaan Masyarakat}

Konsepsi pemberdayaan masyarakat pada program PNPM MP, Desa Peradaban, CSR dan Posdaya memfukuskan pada metode pendekatan yang diimplementasikan dalam setiap program. Kemudian melihat realitas lapangan pada programprogram tersebut dalam kaca mata skema tingkatan partisipasi Arnstein (1969). Skema tingkatan partisipasi masyarakat dalam memutuskan kebijakan ada tiga tingkat utama (Citizen Power, Tokenism dan Non-partisipation) dan delapan sub-tingkatan, yaitu: (a). Citizen control: yaitu masyarakat mengendalikan kebijakan publik mulai dari perumusan, implementasi hingga evaluasinya; (b). Delegated power: Berarti pemerintah memberikan kewenangan kepada masyarakat untuk mengurus sendiri beberapa keperluannya dalam suatu program pembangunan; (c). Partnership: adanya kemitraan antara pemerintah dan masyarakat dalam program pembangunan; (d). Placation: melibatkan warga untuk menjadi anggota komite dalam program namun hak memutuskan tetap berada pada pemerintah menjadi anggota komite dalam program namun hak memutuskan tetap berada pada pemerintah; (e). Consultation: Adanya komunikasi dua arah seperti survey sikap, pertemuan warga, dan dengar pendapat; (f). Information: Hanya ada komunikasi satu arah dari pemerintah kepada masyarakat seperti pengumuman, pamflet, poster, laporan tahunan; (g). Therapy: Bertujuan tidak untuk mendorong rakyat untuk berpartisipasi melainkan untuk mendidik rakyat; (h). Manipulation: Masyarakat diarahkan agar tidak merasa dipaksa untuk melakukan sesuatu, namun sesungguhnya diarahkan untuk berperan serta.

Secara teknis, metode pendekatan yang digunakan dalam pemberdayaan masyarakat pada program PNPM MP adalah dengan pendekatan partisipatif. Dalam pendekatan partisipatif ini difasilitasi tenaga pendampingan Fasilitator. Masyarakat desa Urug Kabupaten Bogor belum sepenuhnya berperan serta secara aktif dalam pelaksanaan proses perencanaan PNPM MP. Hal ini disebabkan pendekatan partisipasi yang didesign dalam PNPM MP pada dasarnya bersifat top down karena partisipasi menjadi prasyarat dan mekanisme yang diwajibkan dari pemerintah pusat sebagaimana 
diatur dalam PTO PNPM MP. Desa Urug merupakan desa adat memiliki karakteristik tersendiri, dimana kepemimpinan adat dijabat oleh Kikolot dan sekaligus merangkap sebagai kepala desa sehingga memiliki pengaruh besar dalam tata kelola pemerintahan dan kehidupan masyarakat adat. Kikolot yang dibantu oleh Kikolot Amat atau Kokolot Tengah mempunyai peran yang sangat besar untuk memobilisasi masyarakat dalam kesepakatan adat. Kondisi ini dimanfaatkan oleh Kikolot dalam mobilisasi masyarakat untuk berperan aktif (partisipasi) pada PNPM MP. Dilihat dari tingkatan partisipasi masyarakat Desa Urug, cenderung pada kategori non partisipatif dengan tingkat therapy dan manipulation. Partisipasi yang berkembang di Desa Urug masih dimobilisasi dan belum berdasarkan kesadaran masyarakat sendiri untuk ikut terlibat dalam program, karena partisipasi masyarakat berdasar kepatuhan kepada pemimpin (Kikolot). Dengan demikian, metode partisipatif yang dikembangkan PNPM MP masih bersifat mobilisasi sesuai karakter Desa Urug.

Program Desa Mandiri dalam Perwujudan Desa Peradaban di Desa Nyalindung Kabupaten Barat menggunakan metode pendekatan partisipatif. Untuk meningkatkan sinergitas, efisiensi dan efektiftas pelaksanaan pembangunan desa, dengan memberdayakan masyarakat dan diinisiasi pemerintah desa. Desa Nyalindung sebagaimana desa-desa di wilayah Jawa Barat lainnya yang pernah mendapat bantuan program PNPM MP ataupun program lainnya yang menggunakan tenaga pendampingan/ fasilitator telah merubah cara pandang untuk terlibat dalam proses pembangunan desa. Masyarakat sudah penuh kesadaran untuk mengendalikan program kegiatan mulai dari perumusan, implementasi hingga evaluasinya. Sepanjang adanya kejelasan dan kepastian kegiatannya. Adanya program yang bentuknya hibah, bantuan ataupun program pembangunan yang bersifat kemitraan antara pemerintah dan masyarakat maka partisipasi masyarakat sangat tinggi. Dalam pendekatan partisipasif ini terjadi komunikasi dua arah, antara lain dalam pertemuan warga, musyawarah dusun dan musyawarah desa ataupun diskusi dengan pendamping/ fasilitator. Berbeda dengan kegiatan Musrenbang Desa, dimana menurut warga kegiatan dan program yang dihasilkan lebih tidak pasti, sehingga wajar bila partisipasi masyarakat sangat rendah. Mereka yang ikut berpartisipasi hanya masyarakat tertentu saja. Dengan demikian, dilihat dari tingkatan partisipasi masyarakat Desa Nyalindung cenderung pada kategori partisipatif dengan tingkat partnership.

Berbeda dengan metode pendekatan yang digunakan dalam program CSR Pertamina yaitu mobilisasi, tetapi dalam pelaksanaannya pendekatan yang digariskan tidak berjalan. Hal ini disebabkan masyarakat begitu aktif tanpa dimobilisasi. Berbagai kegiatan dan terobosan inovatif bersama pemerintah desa telah dilaksankan dari mengurus lansia sampai anak berkebutuhan khusus. Bentuk partisipasi yang dikembangkan pada program CSR Pertamina oleh perusahaan mengarah pada partisipasi semu (pseudo participation) seperti konsep Sumodiningrat dalam Sulistiyani (2004). Namun dalam pelaksanaannya justru menjadi full participation, karena masyarakat aktif terlibat dalam pengambilan keputusan yang menyangkut pelaksanaan program.

Metode pendekatan yang digunakan dalam pemberdayaan masyarakat pada program Posdaya di Situgede adalah dengan metode partisipatif. Namun demikian metode partisipasif yang diterapkan Program Posdaya Lingkar kampus IPB dilakukan secara bertahap. Dimana pada awalnya pendekatan dilakukan dengan mobilisasi, kemudian setelah berjalan dan seiring dengan perkembangan partisipasi masyarakat maka dengan sendirinya pendekatan partisipasif dapat dilakukan sepenuhnya. Tingkatan partisipasi masyarakat Situgede, cenderung pada kategori non partisitipatif dengan tingkatan therapy dan manipulation. Karena pada awal-awal pengenalan program para kader berkerja keras dalam menggerakkan masyarakat apalagi pada program ini hanya mengandalkan swadaya murni tidak banyak diikuti oleh pendanaan yang memadai sebagaimana program-program lain di atas seperti PNPM MP dan Desa Peradaban.

Sementara kelembagaan pendukung program yang dimaksud pada kajian ini adalah kelembagaan yang dibentuk untuk membantu pelaksanaan program baik didesign bersamaan dengan program tersebut maupun berdasarkan inisiatif pelaksana program di lapangan. Kelembagaan pendukung program pada PNPM MP didesign dari tingkat nasional sampai tingkat desa sudah ditentukan secara hierarkis kelembagaan yang memiliki peran masingmasing. Model kelembagaan seperti ini belum optimal karena keterlibatan pemerintah provinsi sampai dengan pemerintah desa secara struktural tidak terlibat langsung dalam tahapan pelaksanaan PNPM MP. Keterlibatan pemerintah desa baru sebatas memfasilitasi pembentukan kelembagaan masyarakat sebagai lembaga fungsional PNPM MP sebagaimana diatur dalam PTO. Kondisi ini menjadi permasalahan ketika pemerintah desa melaksanakan fungsi pelayanan dan pemberdayaan masyarakat. Keterlibatan pemerintah desa yang dikembangkan PNPM MP belum sesuai yang diamanatkan oleh UU No. 6 Tahun 2014 dan PP No 43 Tahun 2014 yang menyaratkan penguatan peran pemerintah dalam pemberdayaan masyarakat. Kelebihan dari pendekatan kelembagaan pemerintah sudah memasukkan fasilitator atau tenaga pendamping, sesuai dengan UU No. 6 Tahun 2014 pasal 112 ayat 4 menyebutkan bahwa: pemberdayaan masyarakat Desa sebagaimana dimaksud pada ayat (3) dilaksanakan dengan pendampingan dalam perencanaan, pelaksanaan, dan pemantauan Pembangunan Desa dan Kawasan Perdesaan. 
Kelembagaan pendukung program dalam pemberdayaan masyarakat pada Program Desa Mandiri dalam Perwujudan Desa Peradaban, bahwa pemerintah desa secara struktural terlibat aktif dalam pelaksanaan Program. Pemerintah desa mengkoordinir dan mengikuti proses dan perkembangan perencanaan, pelaksanaan, pemantauan dan evaluasi program. Disamping itu pemerintah desa memfasilitasi pembentukan kelembagaan fungsional dan meningkatkan peran dan fungsi lembaga masyarakat BPD, LPM, Organisasi Keswadayaan Masyarakat Setempat (OKMS) dan lembaga kemasyarakatan lainnya terutama dalam menjalankan fungsi kontrol sosial terhadap pelaksanaan program-program pembangunan desa. Dalam hal ini pemerintah desa untuk menyusun RKPdes dan RPJMDes yang ditetapkan dengan peraturan desa. Disamping pemerintah desa, masyarakat juga didampingi oleh Pendamping Administratif dan Pendamping Program untuk menunjang keberhasilan sinergitas dan kesinambungan program.

Pemerintah desa yang dikembangkan Program Desa Mandiri dalam Perwujudan Desa Peradaban sesuai dengan UU No. 6 Tahun 2014 dan PP No 43 Tahun 2014 dimana dalam peraturan tersebut mengamanatkan penguatan peran pemerintah dalam pemberdayaan masyarakat. Kelebihan dari model pemberdayaan masyarakat terkait dengan keterlibatan pemerintah sudah memasukkan fasilitator atau tenaga pendamping. Hal ini sesuai dengan UU No. 6 Tahun 2014 pasal 112 ayat 4 menyebutkan bahwa: pemberdayaan masyarakat desa sebagaimana dimaksud pada ayat (3) dilaksanakan dengan pendampingan dalam perencanaan, pelaksanaan, dan pemantauan Pembangunan Desa dan Kawasan Perdesaan. Hal ini menunjukkan model pendampingan masih relevan untuk model pemberdayaan masyarakat sesuai dengan UU No. 6 Tahun 2014.

Pendekatan kelembagaan pemerintah dalam pemberdayaan masyarakat pada Program CSR Pertamina di Desa Kertajaya Kabupaten Bandung Barat, bahwa pemerintah desa sebagai mitra Pertamina secara struktural berperan sangat besar dalam pelaksanaan Program. Selain pemerintah desa terlibat dalam program sesuai dengan tugas dan fungsinya untuk memberdayakan, masyarakat juga didampingi perusahaan dan pendamping dari UNPAD. Keterlibatan pemerintah desa yang dikembangkan Program CSR Pertamina sesuai dengan UU No. 6 Tahun 2014 dan PP No 43 Tahun 2014 dimana dalam peraturan tersebut mengamanatkan penguatan peran pemerintah dalam pemberdayaan masyarakat.

Pendekatan kelembagaan pemerintahan pada Posdaya, bahwa pemerintah desa secara struktural tidak terlibat langsung dalam tahapan pelaksanaan program. Keterlibatan pemerintah desa baru sebatas pada mendukung pelaksanaan program. Keterlibatan pemerintah desa yang dikembangkan Posdaya kurang sesuai dengan UU No. 6 Tahun 2014 dan PP No 43 Tahun 2014 dimana dalam peraturan tersebut mengamanatkan penguatan peran pemerintah dalam pemberdayaan masyarakat. Kelebihan dari pendekatan kelembagaan pemerintah sudah memasukkan fasilitator atau tenaga pendamping, sesuai dengan UU No. 6 Tahun 2014 pasal 112 ayat 4 menyebutkan bahwa: pemberdayaan masyarakat Desa sebagaimana dimaksud pada ayat (3) dilaksanakan dengan pendampingan dalam perencanaan, pelaksanaan, dan pemantauan Pembangunan Desa dan Kawasan Perdesaan.

\section{Partisipasi Masyarakat pada Program Pemberdayaan}

Menganalisis partisipasi masyarakat pada tahap perencanaan, pelaksanaan, pemantauan dan evaluasi mengacu pada Ericson dalam Slamet (1994) mengenai bentuk partisipasi masyarakat dalam pembangunan. Meski dalam teorinya hanya membagi 3 tahapan yaitu perencanaan, pelaksanaan dan pemanfaatan. Namun pada tulisan ini berupaya melengkapi tahapan tersebut dengan pemantauan dan evaluasi. Rasionalisasi dari pengisian kekosongan ini mengingat pemantauan adalah proses pengumpulan informasi (data dan fakta) yang berhubungan dengan pengambilan keputusan. Sementara evaluasi idealnya melekat dalam perencanaan program agar keberhasilan program sesuai dengan perencanaan program. Lebih mendalam, Hetifah $\mathrm{Sj}$. Soemarto (2003) menyatakan bahwa partisipasi masyarakat adalah proses ketika warga sebagai individu maupun kelompok sosial dan organisasi, mengambil peran serta ikut mempengaruhi proses perencanaan, pelaksanaan, dan pemantauan/ evaluasi kebijakankebijakan yang langsung mempengaruhi kehiduapan mereka.

Secara umum Page dan Czuba (1999) mendefinisikan pemberdayaan sebagai proses membantu masyarakat mendapatkan kontrolnya atas kehidupan mereka sendiri. Proses yang mendorong kekuasaan (dalam hal ini kemampuan untuk melakukan sesuatu) pada masyarakat untuk menggunakan kekuasaannya tersebut pada kehidupannya, komunitasnya, masyarakatnya, dengan melaksanakan sesuatu yang menurut mereka penting untuk dilakukan. Sementara Ife (1995) memfokuskan pemberdayaan pada kekuasaan (power) dimana pemberdayaan bertujuan untuk meningkatkan kekuasaan orang-orang yang lemah atau tidak beruntung.

\section{Partisipasi Masyarakat dalam Perencanaan}

Untuk memandirikan masyarakat dalam perencanaan pada PNPM MP dilakukan dengan pendekatan bottom up system dan difasilitasi dengan tenaga pendampingan/ fasilitator. Pada pendekatan ini masyarakat dilibatkan dalam penggalian gagasan sampai dengan musdes perencanaan disebut dengan 
istilah Menggagas Masa Depan Desa (MMDD), prioritas usulan sampai dengan MAD penetapan usulan. Partisipasi masyarakat di Desa Urug dalam perencanaan PNPM MP secara normatif sudah sesuai dengan tahapan kegiatan perencanaan pada PNPM MP sebagaimana diatur dalam PTO, namun demikian keikutsertaan masyarakat masih bersifat partisan. Dalam pengambilan keputusan pada perencanaan masih didominasi oleh elit lokal (Kikolot). Partisipasi yang berkembang di desa Urug dalam proses penyusunan perencanaan, sesuai dengan adat dan kebiasaan masyarakat hanya menyetujui apa yang dikemukakan oleh Kikolot dan pemuka adat lainnya. Kondisi ideal mengenai proses partisipasi masyarakat dalam perencanaan belum sesuai dengan partisipasi masyarakat di Desa Urug, dimana dalam setiap pertemuan, ide-ide dan inisiatif datang dari elit lokal sedangkan masyarakat belum memberikan gagasan, saran maupun kritik. Hal ini sesuai dengan tingkatan partisipasi masyarakat Desa Urug yang bersifat partisan pada kategori non partisipatif dengan tingkat therapy dan manipulation.

Untuk memandirikan masyarakat dalam perencanaan pada Program Desa Mandiri dalam Perwujudan Desa Peradaban dilakukan dengan pendekatan bottom up system dan difasilitasi dengan tenaga pendampingan dari UNPAD. Pada pendekatan ini masyarakat dilibatkan dalam penggalian gagasan, dan musdes. Partisipasi masyarakat dalam tahap perencanaan Program, mampu mendorong tumbuh dan berkembangnya prakarsa dan swadaya gotong royong masyarakat, partisipasi masyarakat serta transparansi, serta mampu meningkatkan kapasitas kelembagaan dan organisasi yang berakar pada masyarakat desa. Dengan kata lain, telah berada pada kategori tokenism dengan tingkatan consultation.

Dalam memandirikan masyarakat pada perencanaan program CSR Pertamina yang semula didesain dengan pendekatan mobilisai, tetapi dalam pelaksanaannya dilakukan dengan pendekatan bottom up system. Dalam tahap perencanaan, aspirasi datang dari masyarakat, musyawarah 1 (satu) tahun sekali, masyarakat merumuskan prioritas yang akan dilaksanakan, dan masyarakat diberi keleluasaan kemudian disesuaikan dengan prioritas anggaran. Dalam pengambilan keputusan pada perencanaan semua pihak berperan aktif sehingga masuk kategori citizen power dengan tingkatan partnersip.

Dalam memandirikan masyarakat pada perencanaan program Posdaya dilakukan dengan pendekatan bottom up system dan difasilitasi dengan tenaga pendampingan dari IPB. Pada pendekatan ini masyarakat dilibatkan dalam pertemuan yang merumuskan program kerja, membahas berbagai kendala dan solusi mengisyaratkan adanya proses berkelanjutan, dari perumusan masalah, pemecahan masalah, dan tindak lanjut kegiatan yang harus dilaksanakan pada tahapan berikutnya. Proses ini adalah social learning dimana terdapat proses belajar dan mengajar artinya masyarakat diberi kesempatan untuk mengumpulkan fakta dan keadaan serta merumuskan sendiri masalah dan cara pemecahan masalah begitu pula fasilitator berupaya belajar dari pengalaman masyarakat. Perencanaan yang seperti ini merupakan proses koordinasi untuk menggerakkan semua pihak agar berpartisipasi dan menjadikan tujuan kegiatan dapat tercapai seperti yang diinginkan serta memberi kesempatan evaluasi proses dan hasilnya. Sebagaimana yang diungkapkan Lawrence dalam Mardikanto dkk (2013) bahwa perencanaan program menyangkut perumusan tentang: (1) proses perancangan program; (2) penulisan perencanaan program; (3) rencana kegiatan; (4) pelaksanan program; (5) rencana evaluasi hasil pelaksanaan program. Namun karena pada tahap ini masih didominasi peran kader maka masuk dalam kategori non partisipatif dengan tingkatan therapy.

\section{Partisipasi Masyarakat dalam Pelaksanaan}

Proses memandirikan masyarakat pada pelaksanaan program PNPM MP dilakukan dengan mengedepankan keterlibatan masyarakat. Dalam program ini masyarakat sebagai pelaksana kegiatan. Dengan bantuan dana PNPM, masyarakat dapat mandiri untuk melaksanakan kegiatan program, khususnya pembangunan fisik desa sangat dibutuhkan dan dirasakan manfaatnya. Dalam kegiatan ini swadaya dan gotong royong masyarakat adalah tinggi. Yang membedakan Desa Urug dengan desa lainnya, Desa Urug masih memegang teguh adat istiadat. Model partisipasi masyarakat pada tahap pelaksanaan yang dikembangkan PNPM MP, pada dasarnya dapat diterapkan di semua tingkatan partisipasi sesuai konsep Arnstein mengenai skema tingkatan partisipasi masyarakat dalam memutuskan kebijakan. Tingkatan partisipasi masyarakat termasuk pada tingkatan citizen power dengan sub tingkatan delegated power (pemerintah memberikan kewenangan kepada masyarakat untuk mengurus sendiri beberapa keperluannya dalam suatu program pembangunan) karena masyarakat berpatisipasi aktif dalam bentuk pikiran, tenaga dana dan material pada pelaksanaan kegiatan PNPM MP.

Untuk memandirikan masyarakat pada pelaksanaan program Desa Mandiri dalam Perwujudan Desa Peradaban di Desa Nyalindung dilakukan dengan meningkatkan partisipasi dan peran kelembagaan masyarakat dalam pembangunan. Strategi dilakukan dengan: mendorong tumbuh dan berkembangnya prakarsa dan swadaya gotong royong masyarakat, partisipasi masyarakat serta transparansi; dan meningkatkan kapasitas kelembagaan dan organisasi yang berakar pada masyarakat desa. Dalam pelaksanaan program, Kepala Desa hanya menekankan keberhasilan kegiatan sementara uangnya diserahkan pada pelaksana kegiatan. Keterlibatan masyarakat dalam pelaksanaan terlihat pada OKMS seperti: pembuatan 
kolam renang 1 hari melibatkan 20 - 25 orang selama 3 bulan. Pada program ini ada keterlibatan BUMDes dalam pengelolaan. Tingkatan partisipasi masyarakat termasuk pada tingkatan citizen power dengan sub tingkatan delegated power (pemerintah memberikan kewenangan kepada masyarakat untuk mengurus sendiri beberapa keperluannya dalam suatu program pembangunan) dan partnership (adanya kemitraan antara pemerintah dan masyarakat dalam program pembangunan) karena masyarakat berpatisipasi aktif dalam bentuk pikiran, tenaga dana dan material pada pelaksanaan kegiatan.

Untuk memandirikan masyarakat pada pelaksanaan program CSR Pertamina di Desa Kertajaya dilakukan dengan meningkatkan peran kelembagaan masyarakat. Partisipasi masyarakat terhahap pelaksanaan program terfokus pada pelaksanaan pembangunan fisik dan renovasi. Tingkatan partisipasi masyarakat termasuk pada tingkatan citizen power dengan sub tingkatan partnership (adanya kemitraan antara pemerintah dan masyarakat dalam program pembangunan) karena masyarakat berpatisipasi aktif dalam bentuk pikiran, tenaga dana dan material pada pelaksanaan kegiatan ataupun program.

Untuk memandirikan masyarakat pada pelaksanaan program Posdaya dilakukan dengan meningkatkan peran anggota masyarakat dalam hal ini khususnya keluarga anggota Posdaya. Dalam pelaksanaan program Posdaya umumnya masyarakat terlibat aktif diberbagai kegiatan baik pada bidang pendidikan, kesehatan, dan lingkungan kemudian berkembang pemberdayaan ekonomi dengan kewirausahaan sebagai perluasan kegiatan.

Tingkatan partisipasi masyarakat termasuk pada tokenism dengan sub tingkatan placation, yaitu melibatkan warga untuk menjadi anggota komite dalam program namun hak memutuskan tetap berada pada pemerintah. Dalam konteks Posdaya peran pemdes kurang terlibat hanya sebatas mengetahui saja dan memfasilitasi sekedarnya. Realitasnya ini dikemukakan oleh pengurus Posdaya. Namun ketika eksistensi Posdaya tetap eksis dan mampu mengambil keputusan diluar pemerintah desa bahkan memberi kontribusi pada bidang pendidikan dan kesehatan serta menjaga keberlanjutan program. Keberlanjutan disini bermakna institusionalisasi dan menularkan pemberdayaan Posdaya ke RW-RW tetangga.

\section{Partisipasi Masyarakat dalam Pemantauan}

Dalam memandirikan masyarakat pada pemantauan program PNPM MP dilakukan dengan membentuk kelompok/ tim pemantau dan menetapkan BPD yang berperan dalam pemantauan kegiatan PNPM MP. Pemantauan yang dilakukan oleh masyarakat dalam PNPM MP meliputi: pengawasan terhadap pengelolaan dan penggunaan dana serta kualitas proyek. Tingkatan partisipasi masyarakat termasuk pada tingkatan citizen power dengan sub tingkatan partnership (adanya kemitraan antara pemerintah dan masyarakat dalam program pembangunan) karena masyarakat aktif melakukan pemantauan langsung yang hasilnya dilaporkan kepada Tim Pemantau dan BPD.

Dalam memandirikan masyarakat pada pemantauan program Desa Mandiri dalam Perwujudan Desa Peradaban dengan melibatkan masyarakat untuk turut serta melakukan pemantauan secara langsung dan melalui lembaga kemasyarakatan seperti LPM, Organisasi Keswadayaan Masyarakat Setempat (OKMS) dan lembaga kemasyarakatan lainnya. Masyarakat dalam melakukan pemantauan/ kontrol bila menemukan kejanggalan atau penyimpangan dalam pelaksanaan program, maka masyarakat melaporkan ke BPD untuk ditindak lanjuti. Sedangkan lingkup pemantauan yang dilakukan masyarakat antara lain: pengawasan penggunaan dana bantuan pemerintah provinsi dan swadaya masyarakat, pemantauan pelaksanaan pembangunan fisik desa.Tingkatan partisipasi masyarakat termasuk pada tingkatan citizen power dengan sub tingkatan partnership (adanya kemitraan antara pemerintah dan masyarakat dalam program pembangunan) karena masyarakat aktif melakukan pemantauan langsung yang hasilnya dilaporkan kepada BPD.

Dalam memandirikan masyarakat pada pemantauan program Program CSR Pertamina di Desa Kertajaya dengan melakukan fungsi control. Fungsi control dilakukan oleh masyarakat/ Lembaga Kemasyarakatan, perusahaan Pertamina dan Pemerintah Desa. Masyarakat disini sangat aktif dalam melakukan control. Masyarakat disini sudah biasa untuk melaporkan kejadian yang merugikan atau terjadi penyimpangan ke BPD ataupun langsung ke Pemerintah Kabupaten. Tingkatan partisipasi masyarakat termasuk pada tingkatan citizen power dengan sub tingkatan partnership (adanya kemitraan antara pemerintah dan masyarakat dalam program pembangunan) karena masyarakat aktif melakukan pemantauan langsung yang hasilnya dilaporkan kepada BPD.

Dalam memandirikan masyarakat pada pemantauan program Program Posdaya dilakukan oleh para kader secara internal, program jumat keliling yang dilakukan oleh IPB dengan para tokoh masyarakat untuk menemukenali permasalahan yang dialami masyarakat dalam pelaksanaan program serta mencarikan solusinya. Pemantauan yang dikembangkan pada Program Posdaya Kenaga tidak dilakukan dengan membentuk kelompok pemantau layaknya kegiatan PNPM MP. Pemantauan yang dilakukan langsung oleh masyarakat, kader, pemdes, tokoh masyarakat dan fasilitator dari mahasiswa juga pakar IPB. Tingkatan partisipasi masyarakat dalam memutuskan kebijakan. Dilihat dari tingkatan partisipasi masyarakat termasuk pada tingkatan citizen power dengan sub tingkatan partnership (adanya kemitraan antara pemerintah dan masyarakat 
dalam program pembangunan) karena masyarakat aktif melakukan pemantauan langsung yang hasilnya dimusyawarahkan dalam rapat/ pertemuan 3 bulanan.

\section{Partisipasi Masyarakat dalam Evaluasi}

Dalam memandirikan masyarakat pada evaluasi program PNPM MP dilakukan secara kelompok dan individu. Secara kelompok lingkup evaluasi pelaksanaan penyusunan laporan. Sedangkan secara individu lingkup evaluasi identik dengan pemantauan yang meliputi evaluasi pada tahap perencanaan, pelaksanaan dan pemantauan. Dalam evaluasi PNPM MP telah ditentukan indikator keberhasilan terkait dengan tingkat partisipasi, tingkat perkembangan kelembagaan, dan jumlah prasarana sarana yang terbangun. Tingkatan partisipasi masyarakat termasuk pada tingkatan citizen power dengan sub tingkatan partnership (adanya kemitraan antara pemerintah dan masyarakat dalam program pembangunan) karena masyarakat berpatisipasi aktif dalam melakukan evaluasi secara langsung maupun melalui kelompok/ pokmas.

Dalam memandirikan masyarakat pada evaluasi program program Desa Mandiri dalam Perwujudan Desa Peradaban dilakukan secara kelompok dalam hal ini melalui LPM, OKMS maupun secara individual yang hasilnya dilaporkan kepada BPD. Secara kelompok lingkup evaluasi pelaksanaan penyusunan laporan. Sedangkan secara individu lingkup evaluasi identik dengan pemantauan yang meliputi evaluasi pada tahap perencanaan, pelaksanaan dan pemantauan. Model partisipasi masyarakat pada tahap Tingkatan partisipasi masyarakat termasuk pada tingkatan citizen power dengan sub tingkatan partnership (adanya kemitraan antara pemerintah dan masyarakat dalam program pembangunan) karena masyarakat berpatisipasi aktif dalam melakukan evaluasi secara langsung maupun melalui kelompok/pokmas.

Dalam memandirikan masyarakat pada evaluasi program CSR Pertamina di Desa Kertajaya, evaluasi hanya dilakukan oleh perusahaan pertamina dan pemerintah desa. Sedangkan masyarakat tidak dilibatkan. Partisipasi masyarakat sebagai social control yang dimaknai sebagai citizen control dalam kategori citizen power.

Dalam memandirikan masyarakat pada evaluasi program Posdaya delakukan dengan melakukan rapat/pertemuan pertiga bulanan bersama dengan masyarakat, kegiatan jumling dan pemantauan dan evaluasi secara internal. Hasil evaluasi dijadikan sebagai dasar upaya perbaikan terhadap kelemahan dan mengatasi hambatan yang terjadi. Tingkatan partisipasi masyarakat masuk pada tingkatan citizen power dengan sub tingkatan partnership.

\section{Kebijakan Antisipatif dalam Mendukung Implementasi Pemberdayaan Masyarakat}

Permasalahan dalam pelaksanaan PNPM MP secara umum karena program ini bersifat add hoc, top down, dan tidak semua desa mendapatkan program PNPM MP. Artinya, pemberdayaan masih bersifat sektoral. Apalagi belum ada peraturan yang eksplisit mengatur pemberdayaan masyarakat (sebelum lahirnya UU No 6 Tahun 2014 tentang Desa). Pengetahuan dan pemahaman masyarakat hanya pada kalangan RW saja yang mengerti apa itu pemberdayaan. Pelatihan-pelatihan dalam rangka capacity building baru sampai di tingkat kelembagaan yang ada di desa. Sedangkan permasalahan yang dihadapi oleh pemerintah desa dalam memberdayakan masyarakat pada PNPM MP ataupun program pemberdayaan secara umum di lingkup desa, pemerintah desa belum melakukan fungsi pemberdayaan masyarakat disebabkan belum adanya pelimpahan kewenangan dan pembiayaan dari pemerintah kabupaten.

Keterbatasan anggaran untuk menjadikan Program Desa Mandiri dalam Perwujudan Desa Peradaban untuk dapat diterapkan diseluruh desa wilayah Jawa Barat, menimbulkan kecemburuan sosial antara desa yang mendapatkan program dengan desa yang tidak mendapatkan program. Terbatasnya aparatur pemerintah desa yang professional dalam bidang perencanaan.

Program CSR/ PKBL selama ini berjalan secara sporadis lebih berdasar kepada keinginan dari pihak perusahaan sebagai donatur itu sendiri, tidak mengacu kepada dokumen-dokumen perencanaan (RPJMD, RKPD, dll) yang sudah ditetapkan baik oleh Pemerintah Provinsi maupun Pemerintah Kabupaten/ Kota. Program hanya di daerah sekitar perusahaan, bantuan bersifat hibah sehingga sulit dalam pengembalian. Selain itu, kesadaran masyarakat pun kurang karena sifat program yang dimobilisasi sehingga wajar bila partisipasi hanya kelompok masyarakat tertentu yang tergabung dalam KSM \& LPMD. Artinya, masyarakat umum hanya berpartisipasi dalam bentuk pemanfaatan program.

Permasalahan dalam pelaksanaan program Posdaya Kenaga secara umum tampak dari lingkup program pokja yang hanya di tingkat RW. Pemerintah desa tidak terlibat secara langsung, kegiatan tidak terintegrasi dengan musrenbang, mengandalkan swadaya murni dari masyarakat dalam hal ini termasuk pendanaan program. Dalam kegiatan ekonomi produktif mengalami kendala pada pemasaran produk. Meski di Posdaya Kenaga sering dikunjungi posdaya lainnya ataupun mahasiswa KKN, mahasiswa study banding dari Luar Negeri seperti Jepang dan lain-lain. Namun belum ada jalur pemasaran produk yang permanen, masih sekedar dari pameran ke pameran saja.

Berdasarkan elaborasi dinamika program pemberdayaan dari PNPM MP, Desa Peradaban, CSR hingga Posdaya untuk itu perlu melihat pemberdayaan masyarakat desa pada UU No. 6 Tahun 2014. Apakah secara konseptual UU No. 6 
Tahun 2014 mampu menjawab permasalahan mendasar pemberdayaan masyarakat? Apakah UU No. 6 Tahun 2014 dapat dijadikan kebijakan antisipatif yang mendukung implementasi model pemberdayaan masyarakat?

UU Nomor 6 Tahun 2014 tentang desa berisikan tema pokok penataan desa, percepatan pembangunan desa, pembinaan kemasyarakatan desa, dan pemberdayaan masyarakat. Khusus pemberdayaan masyarakat berkaitan dengan upaya percepatan pembangunan desa. Sistematisasi terhadap konsep pembangunan desa dapat dilakukan melalui model evaluasi program, yaitu dimulai dari input (masukan), process (pelaksaan, pendampingan, pemberdayaan), output (hasil), outcome (pemanfaatan hasil) dan impact (dampak dari pemanfaatan tersebut).

Terdapat tiga hal yang berkaitan dengan pemberdayaan masyarakat, atau aspek process dari pembangunan desa dan wilayah perdesaan. Pertama, berkaitan dengan etika pembangunan desa (pasal 78). Kedua, berkaitan dengan strategi kolaboratif dalam pembangunan desa. Ketiga, berkaitan dengan pengembangan kelembagaan pendukung pembangunan desa. Aspek pemberdayaan masyarakat menurut UU Desa dapat dilihat pada Gambar 2.

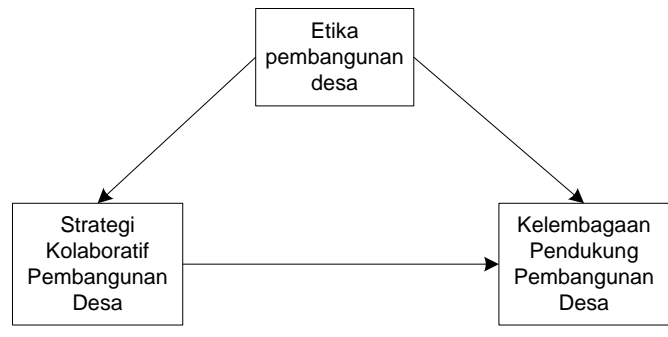

\section{Gambar 2. Aspek Pemberdayaan} Masyarakat Menurut UU Desa

Sumber: Masukan Narasumber (Ivanovic Agusta), 2014

Etika pembangunan desa memberikan basis aksiologis, berupa tata cara untuk melakukan tindakan. Sesuai dengan UU Desa, norma kebersamaan bermakna semangat untuk berperan aktif dan bekerja sama dengan prinsip saling menghargai antara kelembagaan di tingkat Desa dan unsur masyarakat Desa dalam membangun Desa (pasal 3, pasal 78, penjelasan azas pengaturan). Terdapat arah hubungan positif antara lembaga dan warga masyarakat.

Norma kekeluargaan bermakna kebiasaan warga masyarakat Desa sebagai bagian dari satu kesatuan keluarga besar masyarakat Desa (pasal 3, pasal 68, pasal 78, pasal 87, penjelasan azas pengaturan). Arah kesatuan di tingkat desa didasari hubungan positif saling asih-asah-asuh.

Norma kegotongroyongan dalam UU Desa senantiasa melekat dengan norma kekeluargaan.
Norma kegotongroyongan bermakna kebiasaan saling tolong-menolong untuk membangun Desa (pasal 3, pasal 68, pasal 78, pasal 87, penjelasan azas pengaturan). Di sini gotong royong dioperasionalkan sebagai proses tukar menukar riil antar warga.

Norma pengarusutamaan perdamaian memiliki landasan filosofis dalam UUD 1945. Adapun dalam UU Desa konteks perdamaian lebih banyak dikaitkan dengan desa adat (pasal 78, pasal 103, penjelasan dasar pemikiran). Hal ini mengindikasikan peluang perdamaian melalui pemecahan masalah sesuai kebijakan lokal (Alternative Dispute Resolution/ADR).

Norma keadilan sosial bermakna berkaitan dengan keadilan antar jenis kelamin (keadilan gender) dan keadilan di antara golongan sosial dan budaya yang berbeda (pasal 4, pasal 26, pasal 63, pasal 72, pasal 78, penjelasan tujuan pengaturan, sumber pendapatan desa).

Kearifan lokal bermakna, bahwa di dalam penetapan kebijakan harus memperhatikan kebutuhan dan kepentingan masyarakat Desa (pasal 24, pasal 81, penjelasan pembangunan desa dan kawasan perdesaan). Kearifan lokal diperlukan dalam pembangunan desa, yang lazimnya ditunjukkan dalam bentuk pengambilan keputusan berkali-kali.

Pemanfaatan sumber daya alam (SDA) memiliki beberapa makna, yaitu penggunaan potensi alam lokal dalam pembangunan desa, pengelolaan SDA secara berkelanjutan, dan kelembagaan pengelolaan lokal dalam Bumdesa (Badan Usaha Milik Desa) (pasal 78, penjelasan pembangunan desa dan kawasan perdesaan).

Transparansi informasi perencanaan dan pelaksanaan pembangunan desa dilaksanakan di tingkat pemerintahan desa serta di tingkat masyarakat (pasal 68, pasal 86). Proses transparansi diarahkan utnuk menciptakan akses agar masyarakat lebih berperan aktif dalam kegiatan pembangunan.

Pemantauan pembangunan terutama dilakukan oleh masyarakat desa (pasal 68, pasal 80, pasal 82, pasal 112, penjelasan pembangunan desa dan kawasan perdesaan). UU Desa memastikan keluhan warga desa ditanggapi oleh pemerintah desa. Masyarakat diberi hak untuk menghadiri musyawarah desa dalam rangka menanggapi keluhan tersebut.

Dengan banyaknya penyampaian kata kunci keterpaduan pembangunan desa (pasal 81, penjelasan pembangunan desa dan kawasan perdesaan), maka kolaborasi menjadi strategi utama. Aktor yang perlu berkolaborasi dalam proses percepatan pembangunan desa mencakup Pemerintah, Pemerintah Daerah Provinsi, Pemerintah Daerah Kabupaten/Kota, Pemerintah Desa. Tentu dimungkinkan kolaborasi dengan swasta dan LSM atau lembaga kemasyarakatan lain. Arah kolaborasi ialah menuju kemandirian desa (pasal 1). Minimal pembahasan kolaboratif mencakup topik-topik penggunaan SDA desa, penggunaan sumber daya manusia (SDM) desa, 
pengelolaan aset desa (pasal 4, pasal 78, pasal 81, pasal 84, pasal 85, pasal 90, penjelasan pembangunan desa dan kawasan perdesaan). Keputusan pembahasan tersebut hendaknya dilaksanakan oleh Pemerintah Desa, atau dilaksanakan oleh BUM Desa (pasal 26, pasal 81, pasal 90, penjelasan pembangunan desa dan kawasan perdesaan).

Agar proses pembangunan berjalan sesuai dengan kebutuhan masyarakat, maka diperlukan proses pelembagaan (intitutionalization). Pelembagaan mencakup tahapan mengetahui, mengenal, menyetujui keputusan-keputusan yang diambil, dan terakhir menginternalisasikan pembanunan desa tersebut. Di sini pelembagaan penting untuk menjaga keberlanjutan pembangunan di kalangan warga desa sendiri.

UU Desa memberikan arahan pelembagaan untuk percepatan pembangunan desa. Pertama, membentuk badan kerja sama antar-desa (pasal 92). Lembaga ini disusun untuk mengembangkan ekonomi wilayah perdesaan atau lebih luas, atau untuk pembangunan wilayah pada beberapa desa. Kedua, pembentukan kelompok/ lembaga (pasal 94). Kelompok swadaya masyarakat berguna untuk menyatukan daya dan mencapai harapan kesejahteraan warga lebih tinggi lagi. Ketiga, pembentukan BUM Desa (pasal 88), terutama untuk mengelola sumber daya alam lokal dan sumber daya manusia lokal. BUM Desa yang disusun antardesa juga bisa menyatukan potensi ekonomi sehingga memiliki skala ekonomi (economic of scale) yang lebih besar dan lebih menguntungkan. Keempat, musyawarah desa (pasal 54), berupa proses saling bertukar informasi yang digunakan untuk pengambilan keputusan bersama di tingkat desa. Kelima, musyawarah antar-Desa (pasal 92), berupa pembentukan jaringan, pengembangan kerjasama ekonomi antardesa dan pembangunan wilayah. Kegiatan utama di sini juga berupa saling tukar menukar informasi antar desa sehingga suatu keputusan bersama antardesa dapat diwujudkan. Keenam, pelembagaan yang menjadi inisiatif pihak luar desa berupa pendampingan (pasal 90, pasal 112, pasal 114, pasal 115).

Dari aspek mendasar mengenai pemberdayaan masyarakat menurut UU Desa (etika pembangunan desa, strategi kolaboratif dalam pembangunan desa dan pengembangan kelembagaan pendukung pembangunan) serta konteks permasalahan yang terjadi dalam realitas lapangan khususnya pada program-program pemberdayaan yang lahir sebelum adanya UU Desa menjelaskan bahwa etika pembangunan desa yang berisi nilai atau norma jika benar-benar menjadi dasar atau landasan dalam pembangunan desa akan memperkuat desa. Apalagi jika diikat dengan kehadiran kearifan lokal lain yang hidup di desa termasuk dalam penetapan kebijakan. Muaranya permasalahan seperti kecemburuan sosial, kecemburuan antar desa serta peningkatan kapasitas masyarakat dapat terjawab.
Tentunya dengan mengoptmalkan potensi dan kearifan lokal yang ada dengan berpijak pada etika dan norma setempat.

Sementara dalam strategi kolaboratif pembangunan desa mengedepankan keterpaduan antar aktor yang memiliki kesamaan tujuan yaitu percepatan pembangunan desa dengan tidak melupakan proses-proses pemberdayaaan masyarakat sehingga muara kemandirian desa tercapai. Minimal kolaborasi dalam mengoptimalkan SDA desa, SDM perdesaan, pengelolaan aset serta pembangunan desa dan kawasan perdesaan. Konseptualisasi aspek pada UU desa ini diharapkan mampu menjawab permasalahan pemberdayaan yang bersifat sektoral, belum dilibatkannya pemerintah desa maupun institusi yang bersifat striktural dalam pemberdayaan masyarakat. Artinya, mengembalikan fungsi pemerintah sebagai regulator, fasilitator dan katalisator dalam memberdayakan masyarakat. Tentunya dengan prasyarat kerjasama dan kolaborasi antar aktor perlu dikedepankan sehingga masingmasing dapat melaksanakan program sekaligus fungsi kontrolnya. UU No 6 Tahun 2014 ini pun menjawab pelimpahan kewenangan dan pembiayaan termasuk di dalamnya mengenai kekayaan desa, BUM Desa, pembangunan desa, hingga pembangunan kawasan perdesaan yang merupakanperpaduan pembangunan antar desa dalam satu kawasan.

Terakhir, pengembangan kelembagaan pendukung pembangunan hal ini dimaksudkan agar pembangunan berjalan sesuai dengan kebutuhan masyarakat, maka diperlukan proses pelembagaan (intitutionalization). Pelembagaan seperti ini tumbuh dari bawah mencakup tahapan mengetahui, mengenal, menyetujui keputusan-keputusan yang diambil, dan menginternalisasikan pembanunan desa tersebut. Pelembagaan menjadi penting untuk menjaga keberlanjutan pembangunan di kalangan warga desa sendiri. Esensi penting dari pelembagaan mengedepankan musyawarah desa dan musyawarah antar-Desa (pasal 92) yang mampu berfungsi sebagai embrio seklaigus wadah dalam pembentukan jaringan, pengembangan kerjasama ekonomi antardesa dan pembangunan wilayah. Kegiatan utama di sini juga berupa saling tukar menukar informasi antar desa sehingga suatu keputusan bersama antardesa dapat diwujudkan. Proses pelembagaan ini dapat menjadi inisiatif pihak luar desa seperti pendamping/ fasilitator (pasal 90, pasal 112, pasal 114, pasal 115) maupun dari internal desa sendiri dalam hal ini masyarakat dan pemerintah desa yang bersangkutan. Pada akhirnya, institusionalisasi mampu menjawab partisipasi dalam pemberdayaan bahkan mampu meningkatkan partisipasi masyarakat jika mengacu pada konsep dan teori Arnstein. 


\section{KESIMPULAN}

Konsepsi dan kelembagaan pendukung pemberdayaan masyarakat pada program PNPM MP, Desa Peradaban, CSR dan Posdaya. Pemberdayaan masyarakat desa belum sepenuhnya relevan UU No. 6 Tahun 2014 yaitu: metode pendekatan untuk desa adat dengan mobilisasi dan pendekatan pertisipasif untuk desa secara umum; keterlibatan kelembagaan pemerintah desa dalam pemberdayaan secara struktural masih lemah. Pemerintah desa belum melakukan fungsi pemberdayaan masyarakat disebabkan belum adanya pelimpahan kewenangan dan pembiayaan dari pemerintah kabupaten. Partisipasi dalam pemberdayaan masyarakat dilihat dari tahapan partisipasi: (a) Dalam proses perencanaan, dimana kemandirikan masyarakat sebagai muara dilakukan dengan pendekatan bottom up system dan difasilitasi dengan tenaga pendampingan (fasilitator); (b) Pada pelaksanaan program dilakukan dengan melibatkan masyarakat secara langsung sebagai pelaksana kegiatan. Tingkatan partisipasi masyarakat mayoritas pada tingkatan citizen power dengan sub tingkatan delegated power dan partnership; (c) Dalam tahap pemantauan program, masyarakat secara berkelompok maupun individu mengontrol/ memantau program dengan pengumpulan informasi (data dan fakta) guna pengambilan keputusan. Tingkatan partisipasi masyarakat mayoritas pada tingkatan citizen power dengan sub tingkatan delegated power dan Partnership; (d) Evaluasi program dilakukan dengan melibatkan peran aktif masyarakat. Tingkatan partisipasi masyarakat mayoritas pada tingkatan citizen power dengan sub tingkatan partnership.

Dalam merumuskan kebijakan antisipatif sebagai pendukung implementasi pemberdayaan masyarakat ketika dikontekstualkan dengan UU No. 6 Tahun 2014 menekankan pada aspek: (a) keterlibatan aktor penyelenggara pemberdayaan masyarakat; (b) Arah pemberdayaan masyarakat; (c) Aspek kolaboratif pembangunan desa dalam pemberdayaan masyarakat; (d) Pelaksana pemberdayaan masyarakat; (e) Pelembagaan percepatan pemberdayaan masyarakat; dan (f) Etika/ norma pemberdayaan masyarakat.

Mengingat pemberdayaan masyarakat di desa belum sepenuhnya relevan dengan UU No. 6 Tahun 2014, maka perlu inovasi konsep model/ pola yang sudah ada untuk disesuaikan dengan UU No. 6 Tahun 2014, dengan penekanan pada: (a) Keterlibatan aktor penyelenggara pemberdayaan masyarakat; (b) Arah pemberdayaan masyarakat; (c) Aspek kolaboratif pembangunan desa dalam pemberdayaan masyarakat; (d) Pelaksana pemberdayaan masyarakat; (e) Pelembagaan percepatan pemberdayaan masyarakat; dan (f) Etika/ norma pemberdayaan masyarakat; serta (g) pendampingan teknis dan pendampingan akses pasar. Untuk itu, diperlukan penelitian dan pengembangan lebih lanjut dalam menyusun model dan uji coba model sesuai dengan tipologi desa.

\section{Daftar Pustaka}

Arnstein, Sherry R. 1969. A Ladder of Citizen Participation, Journal of the American Planning Association, Vol. 35, No. 4, July pp. 216-224.

Ericson (Slamet, 1994) diunduh dari http://pasca.unand.ac.id/id/wpcontent/uploads/2011/09/analisis-partisipasi masyarakat.pdf

Ife, J.W. 1995. Community Development: Creating Community Alternatives, Vision, Analysis and Practice. Australia: Longman.

Mardikanto, Totok \& Soebiato, Poerwoko. 2013. Pemberdayaan Masyarakat dalam Perspektif Kebijakan Publik. Bandung: Alfabeta.

Page dan C.E. Czuba. 1999. "Empowerment: What is it?”, Jurnal of Extension Vol. 37.

Sumarto, Hetifah Sj. 2003. Inovasi, Partisipasi dan Good Governance. 20 Prakarsa Inovatif dan Partisipatif di Indonesia. Jakarta: Yayasan Obor Indonesia.

Weber, M. 1949. The Methodology of Social Sciences. New York: The Free Press.

Weber, M. 1964. The Theory of Social and Economic Organization. New York: The Free Press.

Weber, M. 1978. Economy and Society, An Outline on Interpretive Sociology, Volume 1. Berkeley: University of California Press. 
100 | Jurnal Bina Praja | Volume 7 Nomor 1 Edisi Maret 2015 : 89 - 100 